Copyright (C) 2017 by Academic Publishing House Researcher

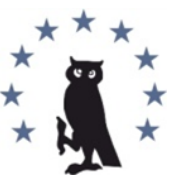

Published in the Russian Federation

European Researcher. Series A

Has been issued since 2010.

ISSN 2219-8229

E-ISSN 2224-0136

2017, 8(4): 313-320

DOI: $10.13187 /$ er.2017.4.313

www.erjournal.ru

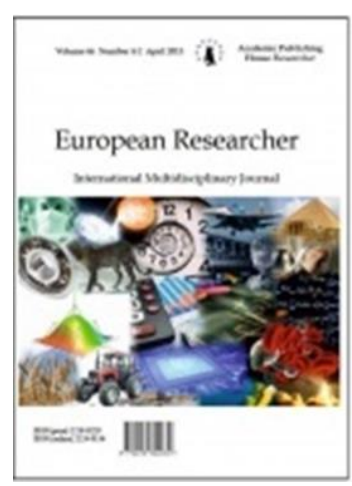

UDC 34.096

\title{
Legal Certainty and Legal Benefit on the Implementation of Laws Article 43 Regarding Flats Number 20 of 2011: Empirical Study on Developer Company Located in South Jakarta
}

\author{
Landya Maria Simatupang a, *, Imam Koeswahyono a, Bambang Sugiri a \\ a Brawijaya University, Indonesia
}

\begin{abstract}
Public Law Norms are created by a state institution through a representative of the people, in which its formation is carefully made, paying attention on the will of the people, with careful and deep preparation, the laws are made of article by article ideally, its rules and sanctions. With regard to the prevailing of a norm over time, it can be questioned that "is the norm effective?" The purpose of this research is to examine how the implementation of Laws Article 43 regarding Flats Number 20 of 2011, and how the form of its arrangement in the future. Sale and Purchase Binding Agreement of the Flats Unit shall be based on Laws Article 43 regarding Flats Number 20 of 2011, and the sale and purchase binding agreement of the territory of private law shall be subject to public law. However, on the contrary, based on the research conducted by the writer, the implementation in the community of two developers who became the object of research does not obey the Laws Article 43 regarding Flats. Article 43 which is distorted by these two developers occurs because the substance of Article 43 paragraph (2) does not provide benefits for developers and customers.
\end{abstract}

Keywords: sale and purchase binding agreement, unit of flats, law of flats.

\section{Introduction}

Laws Number 20 of 2011 regarding Flats governs the flats ranging from land acquisition, licensing, ownership, and also concerns on the establishment of its residents' association. All of that became the developers' initiatives so that customers should also pay attention on developers who have good intentions, (Ming Kirk Tan, 2004). Since the beginning of land acquisition, licensing, signing the sale and purchase and formation of residents association are the initiatives of the Development Agents (Arie, 2007). This study discusses the "ownership of flats" in which Development Agents can market their flats and place of business by signing a Sale and Purchase Binding Agreement (PPJB) in front of a notary. It is regulated in Article 43 of the Law of Flats. Unit Flats Sales are increasingly popular because the property business for people living in urban areas is profitable (Swasto, 2012). In addition to the sale and purchase, property leasing is a consideration

\footnotetext{
${ }^{*}$ Corresponding author

E-mail addresses: landyasimatupang@gmail.com (Landya Maria Simatupang)
} 
that becomes the basis for prospective buyers. The advantages of having a flat implant to be achieved in the short and long term are bigger than deposit interest (Koeswahyono, 2014).

Regarding to the above explanation, the writer is interested in discussing the sales of flat units by examining how the implementation of Laws Article 43 regarding Flats Number 20 of 2011. The marketing of residential and non-residential flats development project must conform to the regulations in the newly-published Law of Flats, specifically Article 43 which regulates the process of sale and purchase before the construction of the finished flats, which contains: 1) The process of buying and selling of flats before the construction is accomplished can be done through Sale and Purchase Binding Agreement (PPJB) made in front of a notary, (2) The Sale and Purchase Binding Agreement (PPJB) as referred to paragraph (1) shall be made after meeting the certainty requirements on: a) Status of Land Ownership; b) Ownership of Building Permit (IMB); c) Availability of public utilities and facilities; d) Construction at least 20\% (twenty percents); and e) The agreed proposition;

Some developers who plan to build in 2011 are skeptical about how the implementation of this new regulation. Developers are made confused by the business side of developers in building flats and places of business, the developers also need certainty of funds from the community. The buyer's assurance although it is still a commitment, but it is necessary to smooth the financial flow (cash flow) of developers (Satrio, 1995; Hamidi, 2017). During the Laws on Flats Number 16 of 1985 regarding Flats Units apply, the developers sell the flats before the construction is finished by selling "pictures" in the form of leaflets containing interesting pictures explaining the product or in the form of a miniature building model that will be made for visualizing the results of the design of the building (Sujatmiko et al., 2014). In performing these sale and purchase transactions, of course, it has binding power as regulated in Article 1338 of the Civil Code (Wijaya, 2017).

As the phenomenon described above about the development, sales and purchase of flat units, and the issuance of the Law of Flats Number 20 of 2011 in Article 43 regarding the requirements of sale and purchase binding agreement, the writer is interested in examining how the implementation of Laws Article 43 regarding Flats Number 20 of 2011 associated with its implementation in two developer companies located in South Jakarta.

From several statements above, there is a formulation of the problem in this study which is how the implementation of Article 43 of the Law of Flats Number 20 of 2011 regarding Flats is associated with legal certainty and benefits?. The purpose of this study is to examine how the implementation of Article 43 of the Law of Flats Number 20 of 2011 and how the form of its arrangement in the future.

\section{Research Method and Research Materials}

The method used in this research is empirical juridical research with sociological-juridical approach. This approach examines the norms of conceptual approach and interview as set forth in Article 43 of the Law of Flats No. 20 of 2011. The research location was at the Office of Company A and Company B which both are leading developers located in South Jakarta. It is based on the consideration that Company A and Company B as developers do sales before the construction is completed after the Law of Flats Number 20 of 2011 with Project "C" and "S" is issued, as set forth in Article 43 paragraph (1), and are willing to be interviewed regarding to the compliance with the requirements of article 43 paragraph (2) although its name is disguised.

Data type and legal materials used in this research are:

1. Primary Data which includes experience of what is done, opinions and statements that the writer obtained based on information from legal developers as resource parties or respondents related to the implementation of Article 43 of the Law of Flats Number 20 of 2011;

2. Secondary Data: The writer obtained secondary data from the Law of Flats Number 20 of 2011, Book of Civil Code, Sale and Purchase Binding Agreement on Flat Units between Company A and Company B with its customers. Primary data source: The writer obtained the results of indepth interviews from assistant head legal at Company A and Company B developer offices located in South Jakarta. Secondary data sources: The writer obtained secondary data from the writer's search results at Brawijaya University's law documentation center, Brawijaya University's library center, University of Indonesia's library, and books related to law, legislation and flats units.

Primary data is analyzed by descriptive qualitative way, by describing the actual behavior portrayed completely, according to the researched problems. On the other hand, hermeneutics 
analysis is employed on secondary data in which the text of the special law of Article 43 is interpreted in order to find the meaning of the script of Article 43 of Act of Flats Number 20 of 2011 in the present research (Hamidi, 2017).

\section{Result and Discussion}

\section{Implementation of Article 43 of the Law of Flats Number 20 of 2011}

The urbanization level reaches 40\% (in 2000), and it is predicted that in 2025 it will increase by about 160 million people or $60 \%$. Thus, the level of urbanization is also accompanied by rapid urban development. Indonesia as a developing country in which its people used to work in agrarian field and in line with development, although not ready yet, its people work in modern industrial sector (Madalina et al., 2015). The above-mentioned explanation explicates how rapid the rate of population growth in Indonesia and urbanization is unstoppable. The movement of rural to urban communities is due to the availability of opportunities for employment and opportunities for business entrepreneurship. However, urbanization leads to the density of the urban population causing irregular settlement problems (slums) and growing population. With the level of good economic establishment, there are still people who are still low-income. The high level of urbanization is also the background of the rampant urban property business (Hutagalung, 2013). Developers and customers are increasingly frequent to buy and sell flats unit in the form of apartments and non-dwelling flats (office/stall) (Rosenfel, 1994).

The developers of Company A and Company B in South Jakarta build "C" and "S" apartment projects both located in South Jakarta. The writer deliberately disguises the name of the developers and projects' names since the data are used only for research purposes.

\subsubsection{Developer of Company A}

Regarding to the interview result with legal of Company A's Developer*, the writer obtained the result that Company A indeed entered into a Sale and Purchase Binding Agreement with its customers with the object of the agreement of Apartment $\mathrm{C}$, while its customer is an individual. Stages undertaken by developer of Company A are Letters of Order, Booking Confirmation, and Sale and Purchase Binding Agreement. The agreement made by Company A is an agreement under lawful act, booking fee payment at Order Letter stage, and is written unit to be purchased, continued by the signing of the booking confirmation whose construction agreement is similar to the sale and purchase binding agreement, that the booking confirmation is clearly stated that there will be a payment of $40 \%$ directly paid to the developer, also in the confirmation of the reservation that the booking confirmation is signed because it has not fulfilled the requirements in article 43 paragraph (2). According to the legal statement of the developer, a sale and purchase binding agreement conducted after the $20 \%$ of the development stage has been fulfilled and all agreements are made under the control. Legal developer of Company A also explained that this new requirement makes financial turnover slow down which usually after signing the PPJB (Sale and Purchase Binding Agreement), 40 \% fund can be disbursed through credit facility, but when enacted this Article 43 paragraph (2), 40 \% fund is paid by the customer by signing the booking confirmation and is paid monthly directly to the developer. It happens since the bank only acknowledges the PPJB (Sale and Purchase Binding Agreement) as a proof that there has been a sale and purchase between the developer and the customer. Besides, the confirmation of the reservation is not recognized by bank as evidence that sale and purchase has occurred and the developer of Company A through interview result also said that this rule is hampering the developer's business.

\footnotetext{
${ }^{*}$ Result of interview with Head Legal of Company A, date of May 312017 conducted at the office of Company A at 17.30 West Indonesia Time that Company A makes PPJB (Sale and Purchase Binding Agreement) with its customers in form of apartment $\mathrm{C}$ as its agreement object, which is recognized when making PPJB and no building progress at all. The developer does sale stage with order stage, booking confirmation, and makes PPJB (Sale and Purchase Binding Agreement). Booking confirmation is recognized as binding evidence between dthe developer and the customer prior to Article 43 verse (2) point (d) is applied. The developer also prefers PPJB (Sale and Purchase Binding Agreement) to be made under lawful act.
} 


\subsubsection{Developer of Company B}

Interview result concerning the fulfillment of binding agreement of sale and purchase of project "S" located in South Jakarta is the building owned by Company B which sold in 2012 is not fulfilling the condition of article 43 paragraph (2) which $20 \%$ of building development, however the developer keeps selling non-residential flats unit (office) purchased by its customers in which a company and an office become the company's assets. For that reason, the developers and customers enter into a notary-based sale and purchase binding agreement. As stipulated in Article 43 of the Law of Flats Number 20 of 2011, both of them made a waiver of Article 43 in the PPJB (Sale and Purchase Binding Agreement) made before the notary and promised not to sue each other and settle all disputes in a deliberative manner. In the end, it is back to the principle of agreement that is the principle of Pacta Sunt Servanda concluded in Article 1338 of the Civil Code ${ }^{*}$ that a judge or third party should respect the substance of the agreement made and obeyed by the parties.

\section{Legal Certainty and Legal Benefit}

3.2.1. Theory of Legal Certainty

As quoted in the book of Bernard L Tanya regarding to the theory of legal certainty formulated by a German philosopher, Gustav Radbruch, he expressed three legal principles: justice (gerechtigkeit), legal certainty (rechtssieherkeit), and legal benefits (zweckmasigkeit). The definition of certainty comes from the word 'certain', which means 'fixed'; already; permanent; must. Gustav Radbruch explicates Scherkeit des Rechts Sebst that legal certainty is the law itself, which means the law is positive and the law is legislation (Poerwadarminta, 2006). Legal certainty is the ultimate goal of the law for orderly and consistent society. Legal certainty means not generating multiple interpretations, logical, and not conflicting with other norms (Bernard, 2013).

In the context of this agreement, the legal certainty covers the certainty of the subject, the certainty of the object, and the certainty of the legal relationship among the parties. Gustav Radbruch cited by Bernard L. Ask et al, legal certainty must be maintained for the sake of security. Certainty reveals the assurance that law contains justice and norms that promote goodness, hence in order to actually function, the rules should be obeyed. The demand for justice and certainty is a permanent part of the law because according to the legality of the law, it is valid for the sake of legal certainty, although it is sometimes recognized that the law is incompatible with individual human development (Bernard, 2013).

From the description of the above discussion, regarding the implementation of PPJB (Sale and Purchase Binding Agreement) when associated with the theory of legal certainty, the writer argues that a norm created by the legislature must be obeyed. The law is positive and the law is legislation. This is for the sake of order in society and for the sake of legal certainty, especially in terms of the certainty of legal subjects, objects, and legal relations in the treaties in which its ultimate goal is justice.

The background of lawmakers in the making of Article 43 of the Law of Flats No. 20 of 2011 is for the protection of customers from fictitious developers who have withdrawn funds from customers. Decision of Society Settlements Ministry is often violated during the Law of Flats Number 16 of 1985 and there are no severe sanctions in it make this rule tend to be ignored. In the academic manuscript of the Law of Flats Number 20 of 2011, it is advisable to be subject to severe sanctions against the offending party.

Norms which are not obeyed by society will cause legal uncertainty. The terms of the agreement provided in Article 1320 of the Civil Code of the PPJB (Sale and Purchase Binding Agreement) made by these developers are null and void in "the Lawful Clause" that the treaty as a private law shall not violate public law. Therefore, in the implementation of PPJB (Sale and Purchase Binding Agreement) realized by the two developers above tend to have no legal certainty because the main terms of article 1320 that not all can be met. At the signing of the agreement, the object of the agreement has not been established yet, and what the developer did by signing the booking confirmation agreement when not yet fulfill the requirements of article 43 paragraph (2) point $d$ also raises the uncertainty of legal relationship between the parties. Developers of Company

\footnotetext{
${ }^{*}$ Article 1338 of Civil Code Book, all agreements made in accordance with laws is prevailing as their laws. The agreements cannot be retaken except both parties' agreements or due to the reasons determined by laws. The agreements shall be conducted with good intention.
} 
B entered into agreement before public officials to the exclusion of Article 43 paragraph (2) of the Law of Flats also results to legal uncertainty.

The writer conducts research on the implementation of the sale and purchase binding agreement of this flat unit is not to find the mistakes made by the two developers. The writer intends to give an idea that a norm whose implementation is disregarded/ignored according to philosopher Gustav Radbuch is a law that fails to guarantee legal certainty in society. The law, which is just the government's willingness, unresponsive, not issued through the process of democratization, and can be expected to satisfy all parties, in this case satisfies the developers and customers.

\subsubsection{Theory of Legal Benefit}

Based on the explication in regards to the infringement of article 43 of the Law of Flats Number 18 of 2011, the writer uses the theory of legal benefit to discuss why the norm tends to be ignored. The writer argues that one of the reasons why the norm tends to be ignored is because it does not provide benefits for society. The writer uses the benefit theory of Jerem my Betham, an English philosopher, quoted in the book Bernard L. Tanya et al., explained that the goal of law is to create the benefit or happiness of society. The meant benefit is the benefit intended for all levels, not the arbitrary benefits, but it is for togetherness, happiness, and prosperity. Ulitilitarism provides a fundamental philosophy that all actions must be determined in the direction and consequences of the future. It is based on the basic nature of human beings who tend to generate profits, benefits, and pleasures. Discussion of the topic in this research about article 43 of Law of Flats in making the regulation should pay attention on how the consequences in the future and the requirements to be fulfilled can be run well by the parties especially developers. Their customers obey the Sale and Purchase Binding Agreement which ignores Article 43 because they do not have a good understanding of the rules of the flat or they have understood about it, but they agree to do the infringement. According to the writer's interview with legal staff of Company A and Company $\mathrm{B}$, both companies recognize that the customer understands the conditions that have not been fulfilled in the making of the sale and purchase binding agreement, and because of the customer's position as the buyer, they ultimately obey what is arranged by the developers.

Regarding to customers' protection which becomes the main purpose of making this article 43, the writer also obtained data from the Indonesian Customer Foundation. The problems complained in the housing sector are development, management, transaction, and many more. The developer is the most complained party by the customer, whether it is about a development, management, and transaction error. It also provides an overview for the writer that the regulations have not been fully adhered and the respondents to which the writer conducts the research are developers who have good credibility, experience in timely building, experience in terms of taking care of timely licensing, and able to manage the turnover of funds. Developers of good category are even unable to comply with the requirements of article 43 paragraph (2).

Absolute requirement of valid sale and purchase binding agreement on flat unit is as stated in Book of Civil Law Article 1320 that there is an agreement between seller and buyer and the ability to act in law. The subjective requirements that must be met between the sellers in this case is the agent of development and legal (halal) cause. Objective requirements that must be met regarding the "Flats" object that is lawful and right of the seller, in this case the agent of development. In addition to the terms of the Agreement pursuant to Article 1320 of the Civil Code since the object of the agreement is the flat unit, the provisions concerning the terms of the sale and purchase agreement must be fulfilled as stated in Article 43 of Law No. 20 of 2011 on Flats, sale and purchase of flat units before construction can be completed. However, they must fulfill the certainty requirements of land ownership status, Building Permit (IMB) ownership, public utilities and facilities availability, at least 20\% of the development and the terms of the agreement. Legal consequences and boundover of ineligible Sale and Purchase Binding Agreement on Flat Units in Article 43 of the Law of Flats No. 20 of 2011.

\section{Legal Consequence}

The consequence is something that becomes the end of an act, whereas according to Soeroso, legal consequence is something that happens from a legal act and a legal event, which consequently regulated by law (Soeroso, 2015). The legal consequence leads to the change of legal circumstances, the change of legal relationships, and for acts against the law resulted in the law of sanctions. In the context of the discussion regarding to sale and purchase binding agreement of flat units, the legal 
consequence made by the agreement of signing this contract is the change of legal relationship which creates rights and obligations between the parties. Rights and obligations as stipulated in Article 570 of Civil Code stated that Right is enjoying the usefulness of a material, while the obligation is the burden given under the law. According to Article 1320 of the Civil Code, the terms of the treaty agreed are such as the ability to make agreements, the existence of certain things or objects, (achievement, buying and selling, money and objects handover), and a lawful cause (geoorloofde oorzaak). The contents of a treaty shall contain a clause permitted or in accordance with the law, so that the agreement becomes valid and binds the parties.

Agreeing and competent in legal action are subjective requirements. The legal consequence that arises as the consequence of the non-fulfillment of the subjective requirement is that the agreement can be canceled if both parties equally cancel it. Terms of agreement of a particular object and a lawful cause are objective conditions. Regarding to the legal consequence of the nonfulfillment of objective conditions, the writer argues that the agreement of sale and purchase binding executed by developers of Company A and Company B result null and void because it is against the law and can be considered that the agreement never exists.

\section{The Power of Binding Agreement}

The contents of the agreement of each articles by its nature govern the terms, rights, and obligations of the parties through negotiation process. If the parties are corporations, then negotiation is there when the drafting process occurs. If the parties are corporations and individuals, the individuals are those who frequently listen to explanations from the developer related to the contents of the agreement section by articles. Herlien Budiono, in his book, wrote the law of agreement in general regulates or it is also called "private law" meaning that the law of agreement embraces the principle of freedom of contract. The law of the treaty includes provisions that are governing the parties*. The sale and purchase binding agreement was born due to the open nature of the Third Book of the Civil Code which provides an opportunity for legal subjects to enter into agreements as long as they do not violate laws, public order, and morals. The agreement is known as the principle of freedom of contract; then for a third party, the principle of pacta sun servanda applies in the sense that a legally binding agreement is only binding on the parties who do so in this sale and purchase agreement. The binding powers under the agreement are set forth in article 1338 of the Civil Ccode of the principle of pacta sunt servanda meaning that the agreement is sacred to those who promise and it is a law for the parties.

The sale and purchase binding agreement of flat units is not solely made by private law, but there is a public element therein. Norms of public law established by the state institutions created that fulfill the will of society based on the norm structure are above private law. Norms in private law are established in accordance with the will of the community formed through civil treaties and are not allowed to conflict with the norms of public law (Bailey et al., 1997).

The Notary of the Supreme Court entered into a sale and purchase agreement in form of a notarial deed for a developer project. Company B recognizes that there are public laws that are omitted/disregarded in this agreement. The Supreme Court Notary makes PPJB (Sale and Purchase Binding Agreement) between the developer parties of Company $\mathrm{B}^{\dagger}$ with its customers

\footnotetext{
* Herlien Boediono, Contract Law if related to the writer's interview result with Legal Project of Company A in May 292017 at the Developer's Office, primary data has been analyzed that contract law applies freedom of contract principle which regulates parties. This freedom of contract that becomes the basis of making the sale and purchase binding agreement between developer of Company A and its customers and the contract which regulates parties is called private law. In this case, the developer and the customer agree to make PPJB (Sale and Purchase Binding Agreement) although both parties recognize that there is a requirement which is not fulfilled yet in Article 43 of the Law of Flats. Both recognize that they will respect and agree the agreement they made and it becomes their basis law.

The writer's interview with legal project of developer; primary data has been analyzed in which the interview has been done in May 292017 at the developer's office, that the developer explained the implementation of PPJB (Sale and Purchase Binding Agreement) for project ' $S$ ' with notary of PPJB with the customer's reason is "Liability Company" and the agreement object is Non-residental Flats (Office), in which the agreement object will be the asset of company; and the last reason is its contract value is high, it causes the developer of Company $\mathrm{B}$ and its customers make a notary of PPJB (Sale and Purchase Binding
} 
because a notary is in charge of serving the needs of society and notary holds on the "will theory" of the parties. From the aspect of legal benefit, a notary performs his/her duties in form of the community came to him to make a notary certificate that is used as a sale and purchase agreement. Notary has explained that there is a public law that must be obeyed in making this purchase binding agreement. It is the duty of the notary to educate the community, but the people still promise to not to sue each other in the future and agree to ignore article 43. Actually, a notary is not the party that executes the contents of the agreement because his/her duty is to witness an agreement by ensuring the date, day of legal deeds, and the community needs a perfect proof in performing this legal act of sale and purchase. The reasons why developers and customers agree to make notarial deed because the value of contracts are quite big and requires legal certainty of assets acquisition that will be reversed on behalf of the company (Scamell, 1961). The purchase of an asset on behalf of a Limited Liability Company impossibly use a deed or other agreement, other than a Sale and Purchase Agreement and a Sale and Purchase Deed.

\section{Conclusions}

The conclusions of this research are as follows

1. The Sale and Purchase Binding Agreement of Flat Units shall be based on Article 43 of the Law of the Flats Number 20 of 2011 and the sale and purchase binding agreement of private law territory shall be subject to public law. However, on the contrary, based on the research conducted by the writer on the implementation in the community, it shows that two developers who became the object of research do not obey the article 43 of the Law of Flats. Article 43 is disrupted by these two developers because the substance of Article 43 paragraph (2) does not provide benefits for developers and customers due to non-compliance of PPJB (Sale and Purchase Binding Agreement) which is not legal in nature, especially the certainty of legal relationship.

2. The two prominent developers in South Jakarta, who are the writer's interviewee, clearly committed infringements of Article 43 of the Law of Flats No. 20 of 2011 and argued that the requirement was only a burdensome for the smoothness of certainty of developer funds. Thus, it is clear that the intention of lawmakers and its implementation are not in line. The responsibility of lawmakers is to establish regulations that protect the just, lawful, and law-abiding societies.

\section{Suggestion}

From the research result, the suggestions are as follows:

1. For lawmakers, it is ideal to make rules with severe conditions and sanctions for the sake of justice and the benefit of bringing order into society. As stipulated in the Law on the Establishment of Law* that the principle of the establishment of the law is one of them in Article 5 (d) "applicable" and point (e) "effectivity and efficiency". The making of Article 43 of the Law of Flats Number 20 of 2011 is intended for customer protection, but the developers who run a business in the field of property development has not been able to implement the requirements prior to the implementation of the agreement binding of sale and purchase of flat units; the main reason is the cash flow: funds from customers are still highly expected to smooth the company's finances in carrying out the development. As the suggestion of this study, it needs a change of conditions which is lighter than the current conditions, so that the purpose of customer protection can still be achieved, although in fact in developing countries such as Indonesia, it has not been able to earnestly apply customer protection due to the company's financial condition.

Agreement). Besides, if at the signing of PPJB, its binding value is as much $40 \%$ transferred to the developer's bank account, so that the customers' funds can smooth the developer's finance.

* Law on the Establishment of Law Number 11 of 2011 Article 5

In establishing the Laws and Regulations, it shall be made on the basis of the Establishment of Good Laws including:

a. Clarity of Purpose

b. Right Institutional or Official establishment

c. Conformity between type, hierarchy, and content material

d. Applicable

e. Effectivity and efficiency

f. Clarity of formulation, and

g. Openness 
2. Developers should continue complying with the legitimate intent of lawmakers not only from the business side, but also from customer protection; should sit together for review requests to amend the legal requirements to achieve legal certainty, legal benefit, rather than continuing committing the infringement of article 43.

3. The writer gives suggestions for future arrangements concerning the requirements of PPJB (Sale and Purchase Binding Agreement) development by developers, that the conditions as set forth in Article 43 of the Law of Flats Number 20 of 2011 can be mitigated, for example, 20\% can be converted to $10 \%$; the availability of facilities and public utilities also mitigated because it is impossible also to wait for the availability of electricity/water, elevators, or parking, while waiting for $20 \%$ for development is too long for developers, or;

4. Terms remain the same as Article 43 of the Law of Flats No. 20 of 2011, but there is an institution or section/division coordinated by the local Housing Department where the location of the flats is placed, specifically to oversee how far the developers have been building.

\section{References}

Arie, 2007 - Arie S. H. (2007). Kondominium Dan Permasalahannya: Edisi revisi. Depok: Badan Penerbit Fakultas Hukum Universitas Indonesia.

Bailey et al., 1997 - Bailey, N., Robertson, D. S., Pawson, H., Lancaster, S., \& Jarvis, C. (1997). Management of flats in multiple ownership: learning from other countries. Policy Press in association with the Joseph Rowntree Foundation.

Bernard, 2013 - Bernard, L. T. (2013). Teori Hukum Strategi Terbit Manusia Lintas Ruang dan Generasi, Cetakan IV, edisi revisi. Yogyakarta: Genta Publishing.

Koeswahyono, 2014 - Koeswahyono, I. (2014). Hukum Rumah Susun Suatu Bekal Pengantar Pemahaman. Malang.

Madalina et al., 2015 - Madalina, M., Purwadi, H., \& Firdausy, A. G. (2015). Meeting the Right to Adequate Housing in Indonesia: National Legal Synchronization Perspective. JL Pol'y \& Globalization, 44, 36.

Ming Kirk Tan, 2004 - Ming Kirk Tan, R. (2004). Restrictions on the foreign ownership of property: Indonesia and Singapore compared. Journal of Property Investment \& Finance, 22(1), 101-111.

Hamidi, 2017 - Hamidi, J. (2017). Hermeneutika Hukum Sejarah Filsafat dan Metode Tafsir, Cetakan Kedua Edisi Revisi. Malang: UB Press.

Hutagalung, 2013 - Hutagalung, A. S. (2013). Execution of Fiduciary Guarantee Under Law No. 42 of 1999 on Fiduciary Guarantee (A Socio-Juridical Analysis to Anticipate Its Effectiveness). Indon. L. Rev., 3, 204.

Poerwadarminta, 2006 - Poerwadarminta, W.J.S. (2006). Kamus Umum Bahasa Indonesia Edisi Ketiga. Jakarta: Balai Pustaka.

Rosenfeld, 1994 - Rosenfeld, M. (Ed.). (1994). Constitutionalism, identity, difference, and legitimacy: theoretical perspectives. Duke University Press.

Satrio, 1995 - Satrio, J. (1995). Hukum Perikatan, Perikatan Yang Lahir dari Perjanjian. Bandung: PT.Citra Aditya Bakti.

Scamell. 1961 - Scamell, E. H. (1961). Legal Aspects of Flat Schemes. Current Legal Problems, 14(1), 161-182.

Soeroso, 2005 - Soeroso, R. (2005). Pengantar Ilmu Hukum. Jakarta: Sinar Grafika.

Swasto, 2012 - Swasto, D. F. (2012). Towards Sustainability: The Creativity of Managing Rental Walk-Up Flats in Yogyakarta, Indonesia. In Proceeding of International Seminar "Artepolis" (4), 5-7.

Sujatmiko et al., 2014 - Sujatmiko, W., Dipojono, H. K., \& Soelami, F. N. (2014). Performance-based fire safety evacuation in high-rise building flats in Indonesia-a case study in Bandung. Procedia Environmental Sciences, 20, 116-125.

Wijaya, 2017 - Wijaya, A. (2017). Hukum Bisnis Properti di Indonesia. Jakarta: Grasindo.

\section{Laws}

Undang-Undang Rumah Susun Nomor 20 Tahun 2011

Kitab Undang-Undang Hukum Perdata

Undang-Undang Nomor 11 Tahun 2011 tentang Pembentukan Undang-Undang

UU Rumah Susun nomor 16 Tahun 1985 